\title{
北研製「ンャンケルリクチン」使用經驗
}

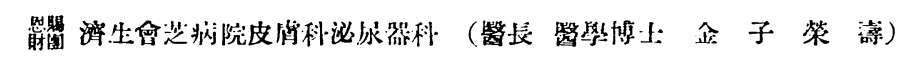

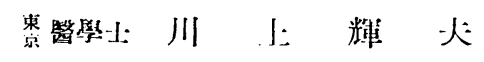

Dermatologische u. Urologische Abteilung des Suiseikai-Shiba Ilospilals von Kaiserliche Stiftung (Iirektor: Dr. E. Kïneko.)

\section{Erfahrungen von Anwendung des Schankervaczins gebracht von Kitasato-Institut. Von}

\section{Teruo Kawakami.}

Von der Forschungsanstalt Hokken (Kitasato-Institut) wurde Verfasser ein Schankervaczin überlassen und damit an den Ambulanten und aufgenommen Kranken der dermatologischen und urologischen Abteilung des Saiseikai-ShibaHospitals der Kaiserlichen Stiftung die Itosche Reaktion und die unblutige Behandlung des Bubos intravenöse Injektion ausgeführt.

Die Gesamtzahl der Versuchsfälle betrug 131. Weicher Schanker : 27 Fälle, Gemischter Schnanker: 13 Fälle, als Romanenz betrachtende Fälle: 1 Fall, Kontrolfalle: 16 Fälle. Die Fälle mit Anwendung von Schankervaczin (vorläufig A und B zu nennen) im Verlauf betragen im Vergleich zum Schankervaczin von Hokken : 17 Fälle, und die behandelten Fälle des Bubos: 11 Fälle.

Zur Bestimmung der Itóschen Reaktion wurden Erytheme im Lokal 48 Stunden nach der intrakutanen Injektion von Antigen beobachtet, und die Erytheme mit über $1.0 \mathrm{~cm}$ Durchmesser als Positv und die sonstigen als Negativ bestimmt. Weiter wurden die Erytheme von einem Durchmesser von $1.0 \mathrm{~cm}$ bis $1.5 \mathrm{~cm}$ mit $(+)$, die von einem Durchmesser von $1.5 \mathrm{~cm}$ bis $2.0 \mathrm{~cm}$ mit $(H)$, uud die von noch grosseren Durchmesser mit (H), bazeichnet.

Die klinisch sicher als weicher Schanker oder als Bubo erkrankten Fälle, die-die Itósche Reaktion nicht aufweisen konnte 5, d. h. 18\% in der 1. Tafel, 8 , d. h. $17 \%$ in der 2. Tafel, 2, d. h, 15\% in der 3. Tafel, 1. d. h. $6 \%$ in der 6. Tafel. Die Itósche Reaktion bei den Kranken mit Bubobehandlung war positiv in $100 \%$. Im Prozent der Gesamtzahl wurde daher die Positivität ca $90 \%$ betragen. 
Die Resultate des in Hokken hergestelletn Schankervaczins sind, wie in der 6. Tafel gezeigt, bei B am geringsten und es ist schwer, dass von Hokken hergestellte mit A zu vergleichen.

Unter den 11 behandelten Fällen von Bubo waren 6 Fälle ausgeheilt. 3 Fälle zeigten von Anfang an deutliche Fluktuation und wurde im Verlauf klein inzisiert, doch wurde der Eiter sofort serös und der Verlauf war ausgezeichnet. In 2 Fälle verkleinerte sich der Bubo nicht ubər einen gewissen Grad. Diese 2 Fälle zeigten positive Frei'sche Reaktion.

Die gesamtdose war durchschnittlich etwa unter $1.2 \mathrm{ccm}$ und sie ist sehr gering im Vergleich $\mathrm{zu}$ anderen Autoren.

Nach der Meinung des Verfassers sollte die Anwendung grosser Dosen möglichst vermieden werden. In dem Fiebertypus der von ihm durchgefuhrten Fieberbehandlung ist besonders das Vorkommen der Doppelzacken interessant. Die 2. Doppelzacke ist niedriger als die I. Die Entstehung und die Bedeutung dieser Doppelzacken sind unklar.

\section{緒 言}

1907年 Pirquet 氏=依リ始メテ結核ニ對スル皮膚反應ガ發表セラレテ以來，コノ種ノ皮膚反 應二對スル研究ハ日ヨ追ツテ旺ントナリ,各種ノモノガ各分科ニ於テ試ミラレルニ到ツタ。

余等ガ日常タッ゙サワル皮泌科領域ニ於テモ諸種疾患二對シ數種ノ皮膚反應ガ試ミラレテキ ル。殊=1913年伊東氏ガ所謂伊東氏反應ナルモノヨ發表シテ以來，西歐ニ於テソノ研究ハ活潑 トナリ，John Reenstierna 氏ノ追試ヨ倚ツテ，ソノ運用ハ皮泌科領域ニ於テ普遍化スル二到 ツタ。最近二於テハ1924年 Nicolle, Durando 氏ガ Dmelcos ナル軟性下痹菌「ワクチン」フ 創製シ，軟性下疳及ソノ横瘁二對スル㟝斷及治療二廣ク使用シテ劃期的ナ成績

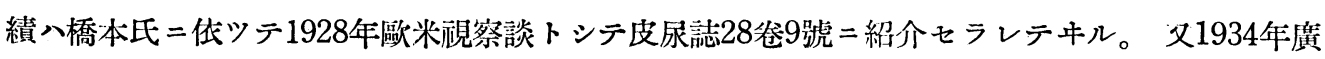

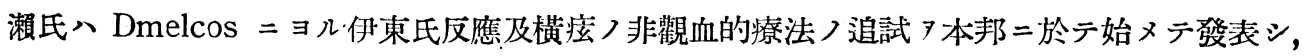
酮來諸家つ報告卜相俟ツテ此處二漸ク軟性下底菌「ワクチン」ガ伊東氏反應ノ優秀ナル抗原卜 シテ，又下疳性橫瘁つ治療藥トシデ吾々つ領域二普遍化スルニ到ツタ。

余八最近北里研究所 $ヨ$ 同研究所製造ニカ、ル軟性下底菌「ワクチン」ノ寄贈ヨ受ケ, 總例131 例 =就テ使用セル 發賣七ラルル製品(假リ $=\mathrm{ABB}$ 及ス)ト比較試驗

\section{北研製「シヤンケルワクチン」ニ就テ}

北研製「シャンケルワクチン」ノ性狀ノ大略习記セバ次つ如クデアル。

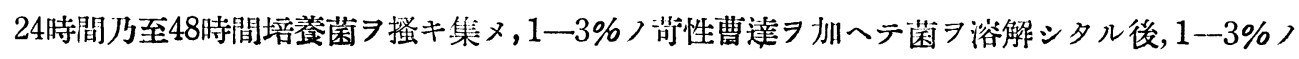




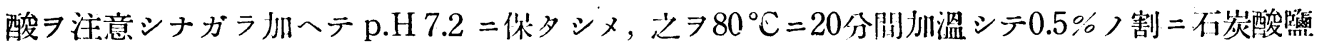
ヨ加へタモノデアル。

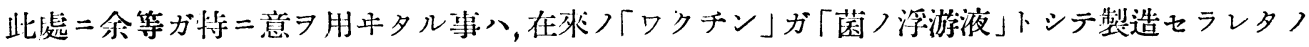
二對シテ，北研製ノモノハ $3 \%$ 菏性曹達ヨ以テ菌體ヨ完全二溶解セシメテ製造シタ菌成分含有 液デアルトイフ點デアル，從ツテ該「ワクチン」八彼ノDmalcos ヨリモ顆粒八遙カ二微細且ツ

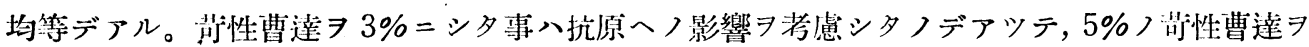
使用スルトキ入菌體六完全二溶解スルガ, 抗原二對シ幾分ノ影響ヨ及ボスヤウデアルトイフ。 該「ワクチン」ノ菌含有量ハ $1.0 \mathrm{cc}=ツ キ 0.4 \mathrm{mg}$ デアル。

\section{北研製「シャンケルワクチン」ニ依ル伊東氏反應}

前述つ如ク1924年佛國二於テ Nicolle Durando 氏ガ Dmelcos ナル軟性下疳菌「ワクチ

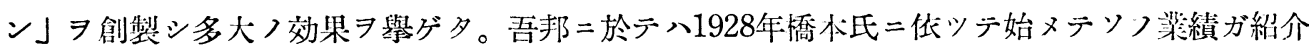
セラレ，1934年廣瀨氏ガ之ヨ追試シテ以來，淺見，速山，市川，愛须，田口氏等つ諸家つ追試ガ 相次イデ發裴セラレタ。カクノ如ク軟性下疳二對スル伊東氏反應ガ旺ン二應用セラレル二到ル ト，现在迄二發賣セラレデタ諸種ノ「シヤンケルワクチン」類ニ對シテモ夫々再檢討ガ試ミ ラレ, 石津, 信岡, 淺見, 熊谷ノ諸氏二低ツテ批判的ナ報告ガ荻表セラレルニ到ツタ。

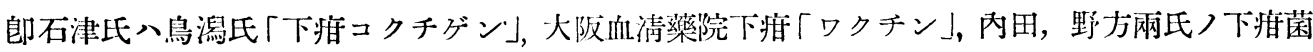

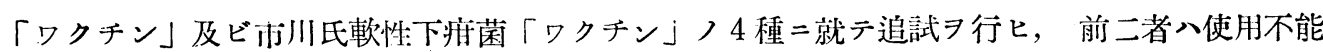

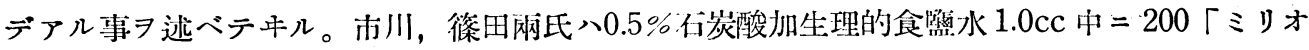

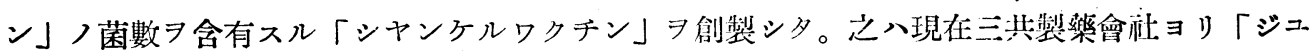

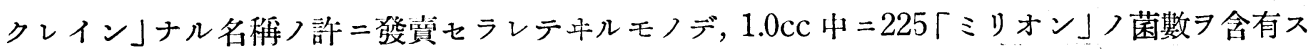
ル Dmelcos = 匹敵スルモノトシテ報告シテキル。

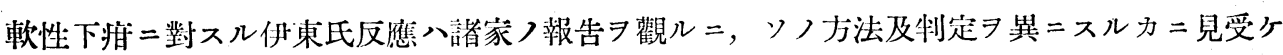
ル。郎本法創案者タル伊束氏二依レバ, 陽性ナルモノ八極メテ高度二發赤シ, 境界銳利ニシテ

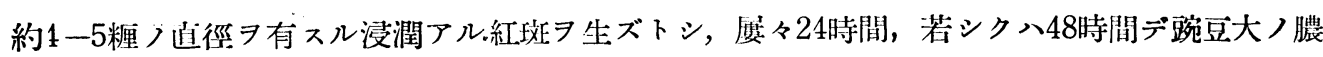
疮习生ズル場合モアルト述ベテキル。而シテ使肘シタ抗原ノ量八1-2滴トナツテキル。Reenstiern a氏=據レバ， $37^{\circ} \mathrm{C} 24$ 時間培養ノ軟性下将菌 1 白金耳 $71.0 \mathrm{cc}$ ノ生理的食邷水二溶カシタ モノヨ抗原トシ，之 72 週間水室二眝藏シタ後コノモノテ $2-3$ 滴皮內二注射シ，成人二於テハ 48 時間後,小兒二於テハ72時䦌後二觀察スルトナシテキル。市川氏八抗原0.1cc 7 皮內二注射シ，

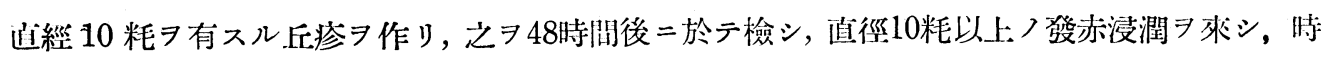

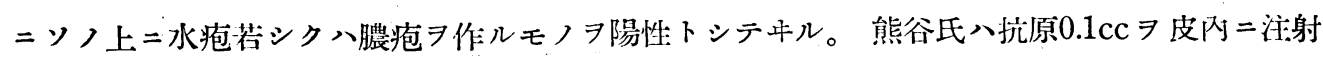

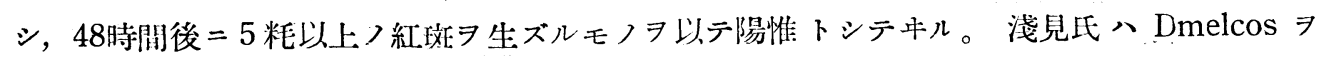

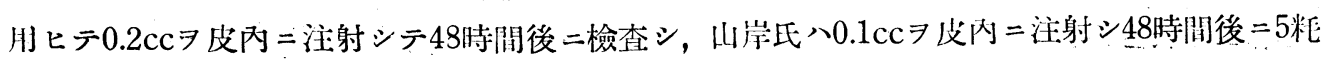


以上ノ紅斑ヨ生ジタモノヨ陽性トシテキル。

如斯諸家ニ依ツテソノ抗原ノ用量乃至八反應ノ判定方法习異ニスルノデアルガ, 余等八伊東 氏反應ノ賽施ニ當ツテ次ノヤウナ術式及判定法ヨ探ツ夕。

北研製「シャンケルワクチン」ヨ精細ナ目盛ヨ有スル「ツベルクリン」注射器二採ツテ精確二

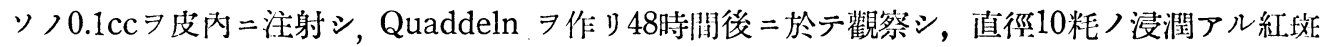
ヨ作ツテキルモノヨ以テ陽性トシタ。郎大體二於テ市川氏等ノ術式及判定法二準據シタノデア ツテ，水疮乃至八膿疮形成八反應つ强キシ示スモノトシテ取披ヒ，以下筫驗例 記シ少ソノ反應度ヨ(十)(甘)（州）ノ附號ヨツケテ示セバ次表ノ如クデアル。

余八值經 1 粝以上ノモノ (州)トシタ。

\section{軟性下疷第 1 表}

\begin{tabular}{|c|c|c|c|c|c|}
\hline 姓: & 年 & 初靾時䩕斷 & 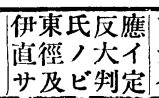 & 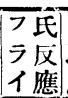 & 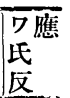 \\
\hline 松同 $\mid 2$ & $20 \hat{\gamma}$ & 軟性下疳 & $1.0 \times 1.0(+)$ & $(-)$ & $(-)$ \\
\hline 位兼屋|2 & $29 \jmath$ & 軟性下疷 & $2.0 \times 1.5(t+)$ & $(-)$ & $(-)$ \\
\hline 3 伊東 2 & \begin{tabular}{|l|l|}
23 & $\jmath$
\end{tabular} & 軟性下底 & $0.8 \times 1.0(+)$ & $(-)$ & \\
\hline 4 野田3 & $30 \hat{o}$ & 軟性下度 & $1.3 \times 1.3(+)$ & & \\
\hline 5 内田3 & $37 \mid \hat{o}$ & 軟性下疳 & $2.0 \times 1.8(t+)$ & $(-$ & $(-)$ \\
\hline 6 佐藤 3 & 31 | & 軟性下病 病 第4 & $5(t+)$ & $(+)$ & $(-)$ \\
\hline 7 小田 2 & $26 \hat{0}$ & 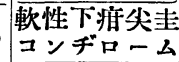 & $3.0 \times 2.8(\mathrm{Ht})$ & & \\
\hline 8 關本3 & 35 คิ & 軟性下疷 & $1.2 \times 1.0(+)$ & & \\
\hline 9 川 & 25 今 & 軟性下疳 & $3.8 \times 4.2(\mathrm{Ht})$ & & \\
\hline 0 阿部 2 & 22 今 & 軟性下疷 & $6(t+)$ & & \\
\hline 1 三國 & $21 \hat{\delta}$ & 軟性下疷 & $0.8>$ & & $(-)$ \\
\hline 2黑田3 & 30 今 & 軟性下病 & $1.8 x$ & & \\
\hline 3 關根 2 & $28 \hat{\circ}$ & 軟性下㭽 & $0.2 \times$ & & \\
\hline 14 遠 & $\left.22\right|_{\delta}$ & 軟性下疷 & $0.2 \times 0.2(-)$ & & \\
\hline 5 本 & 40 웅 & 軟性下疷 & $1.0 \times 1.0(+)$ & & $(-)$ \\
\hline 16有 & & 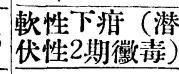 & $1.0 \times 1.2(+)$ & & (HI) \\
\hline 17 伊藤 & $52 \hat{\delta}$ & 軟性下疷 & $1.5 \times 1.5(t+)$ & $(-$ & $(-)$ \\
\hline 8 吉田 & $18 \hat{o}$ & 軟性下痻 & $1.1 \times 1.0(+)$ & & \\
\hline 9 小林 & $24 \mid \widehat{s}$ & 軟性 & $1.0 \times 1.0(+)$ & & \\
\hline
\end{tabular}

\begin{tabular}{|c|c|c|c|}
\hline 20 桃山 26 , 全 & $\begin{array}{l}\text { 軟性下病 (潜 } \\
\text { 伏性2期徽毒) }\end{array}$ & $2.5 \times 2.5(\mathrm{HW})$ & (H) \\
\hline 千代 43 \% & $\begin{array}{l}\text { 軟性下席 (潜 } \\
\text { 忋 } 2 \text { 期徽毒) }\end{array}$ & & $(\mathrm{HI})$ \\
\hline $22^{\text {佐々 } 38 \text { 。 }}$ & 軟性下疳 & $2.0 \times 2.5(\mathrm{H})$ & \\
\hline 3 小出 22 。 & 軟性下疷 & $5($ (\#) & $(-)$ \\
\hline 36 & $\begin{array}{l}\text { 軟性下疷 (潜 } \\
\text { 伏性2期徽毒) }\end{array}$ & & (HH \\
\hline 25 金原 29 o & 軟性下痤 & $1.5 \times 1.5(\mathrm{HI})$ & $(-)$ \\
\hline 26 植林 25 。 & 軟性下庹 & $0.5 \times 0.6(-)$ & $(-)$ \\
\hline 7 小林 27 。 & 軟性下疷 & $0.6 \times 0.7 i-)(-)$ & \\
\hline
\end{tabular}

\section{軟性下㽽及横疾 第 2 表}

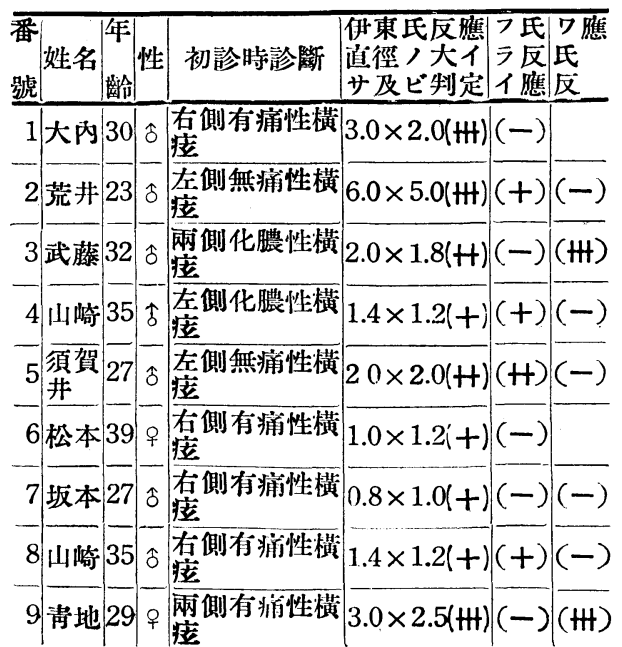




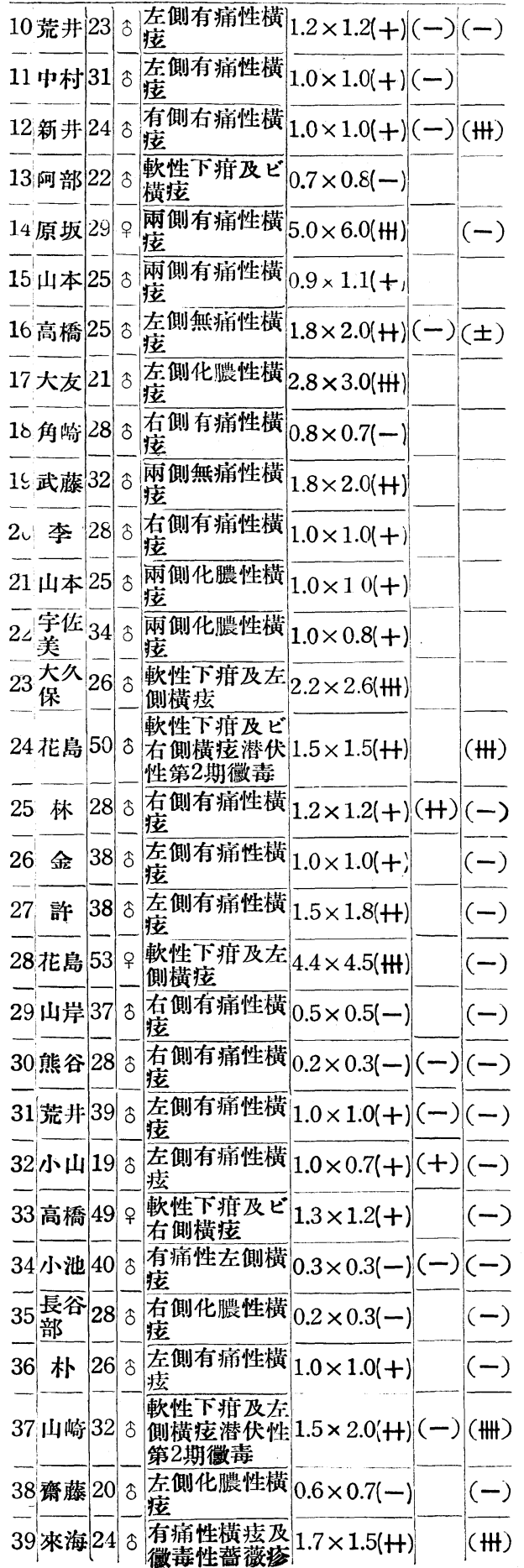

40 東 $42 \mid$ 今 整痛性横瘖 $|0.5 \times 0.6(-)(-)|(\mathrm{W})$ 41 朴 22 今軟性下瘦及有 $1.0 \times 1.1(+)-(-)$ 42 籃谷 25 余軟性下痛及有 $1.0 \times 1.0(+)(-)$

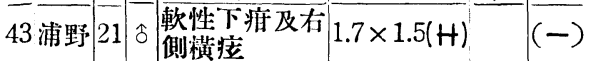

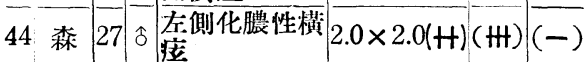
45 市川 33 o 無痛性横瘖 $1.0 \times 1.0(+)(-)(\mathrm{H})$

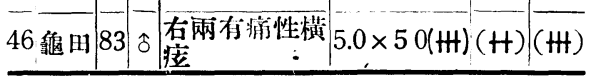

\section{混合下瓶第 3 表}

\begin{tabular}{|c|c|c|c|c|c|}
\hline 姓名 & 年 & 初診日 & \begin{tabular}{l|} 
伊東氏反應 \\
直徑/犬イ \\
サ及ビ判定
\end{tabular} & $\begin{array}{l}\text { 7氏 } \\
\text { 5反 } \\
\text { 應 }\end{array}$ & \begin{tabular}{|l} 
應 \\
氐 \\
反 \\
\end{tabular} \\
\hline 1 遊佐 & $21 \mid \hat{\jmath}$ & 混合卜疷 & $1.0 \times 1.0(+)$ & & (HA) \\
\hline 2 佐野 & $25 \hat{\circ}$ & 混合下府 & $5.0 \times 4.8(\mathrm{HI})$ & & \\
\hline 3 䂝崎 & $36 \delta$ & 混合下痻 & $1.0 \times 1.01+$ & & \\
\hline 4 本井 & $58 \hat{o}$ & 潉合下疷 & $3.0 \times 2.0, \mathrm{Ht}$ & & HI) \\
\hline 5 策 & $25 \hat{\delta}$ & 混合下疷 & $\mathrm{OCH}$ & & (H) \\
\hline 6 山本 & 26 o & 混合 & $8(H)$ & & $(\mathrm{HH})$ \\
\hline 7 齋藤 & $\left.32\right|_{\hat{\delta}}$ & 混合下㾋 & $3.8 \times 1.0(+)$ & & $(\mathrm{Ht})$ \\
\hline 8 青木 & $53 \hat{~}$ & 混合下将 & $1.0 \times 1.0(+$ & & (HI) \\
\hline & 56 ภ & $\begin{array}{l}\text { 混合下疷及左 } \\
\text { 側横瘖 }\end{array}$ & $1.0 \times 1.0(+)$ & & (HA) \\
\hline 10 濱川 & 33 के & 混合下疷 & $05 . \times 0.6(-)$ & & ( $\mathrm{H})$ \\
\hline $1 \mid\}$ & 22 今 & 混 & $(-)$ & & $\begin{array}{l}(-) \\
\text { 讨田 } \\
( \pm) \\
\end{array}$ \\
\hline 2 折原 & $60 \hat{~}$ & 混合 & $3.0 \times 3.0(\mathrm{HH})$ & 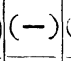 & (H) \\
\hline 13 相磯 & $28 \mid \stackrel{9}{9}$ & 混合下底 & $3.5 \times 3.0(\mathrm{H})$ & & (卅) \\
\hline
\end{tabular}

對照症例 第 4 表

\begin{tabular}{|c|c|c|c|c|c|}
\hline 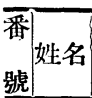 & & 初診時診斷 & $\begin{array}{l}\text { 伊束氏 } \\
\text { 反應 }\end{array}$ & \begin{tabular}{|l|} 
フライ氏 \\
反應
\end{tabular} & $\begin{array}{l}\bar{\nabla} \text { 雔 } \\
\text { 区 } \\
\text { 反 }\end{array}$ \\
\hline 1吉井 & $26 \mid \hat{o}$ & 硬性下病 & $(-)$ & & \\
\hline 2 寄佐 & 34 今 & 硬性下症 & $(-)$ & & \\
\hline 3 筐 & $24 \hat{\delta}$ & 硬性下疷 & $(-)$ & & \\
\hline 4 關 & $29 \hat{\delta}$ & 硬性下症 & $(-)$ & & (H) \\
\hline
\end{tabular}




\begin{tabular}{|c|c|c|c|c|c|}
\hline & 吉川 45 \& & 第四性病 & $(+)$ & $\begin{array}{r}(+) \\
1.0 \times 10 \\
\end{array}$ & $(-)$ \\
\hline 6 & 申 $28 \hat{o}$ & 第四性病方 & $(-)$ & & \\
\hline & 久米 24 方 & 第四性病 & $(-)$ & \multirow[t]{2}{*}{$\begin{array}{r}\text { (HA } \\
5.0 \times 5.0\end{array}$} & \\
\hline 8 & 吉次 28 o & 第四性病 & $(-)$ & & $(-)$ \\
\hline 9 & 金 23 응 & 第四性病 & $(-)$ & $(-)$ & $(-\cdots)$ \\
\hline 10 & 三橋 52 & 第四性痤 & $(-)$ & $(-)$ & $(-)$ \\
\hline 11 & 岸本 40 合 & 第四性病 & $(-1)$ & $\begin{array}{r}(+) \\
1.0 \times 1.0 \\
\end{array}$ & \\
\hline 12 & 金 30 & 第四性疾 & $(-)$ & $\begin{array}{r}(+) \\
1.0 \times 0.8 \\
\end{array}$ & (H) \\
\hline 13 & 师藤 25 。 & 淋疾及徵毒 & $(-)$ & & (HI) \\
\hline 14 & 石田 25 & 淋疾 & $(-)$ & & \\
\hline 15 & 可李 & 淋状 & $(-)$ & & \\
\hline 16 & 6 山田 22 今 & 急性濕疹 & $(-)$ & $(-)$ & \\
\hline
\end{tabular}

第 5 表回顧現 象

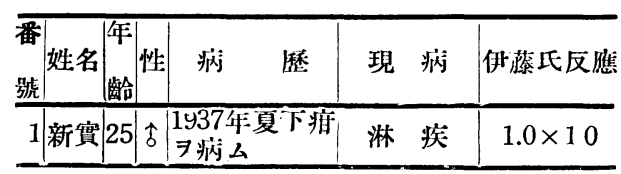

第 6 表 北研及市販 $\mathrm{A}$ 並二B「シヤンケル ワクチン」使用比較例

\begin{tabular}{|c|c|c|c|c|c|c|}
\hline 番姓|年 & & & 伊 & 東 氏 & 反 應 & \\
\hline 號名齡 & & 斷 & A & 北研 & B & 反 \\
\hline $1\left|\begin{array}{l}\text { 倉 } \\
\mid\end{array}\right| 27$ & & 次性 & $1-$ & $0 . \begin{array}{l}1+ \\
1.0 \times\end{array}$ & $0.5 \times 0.5$ & \\
\hline
\end{tabular}

\begin{tabular}{|c|c|c|c|c|c|c|c|}
\hline & & & $\begin{array}{l}\text { 右側有痛 } \\
\text { 性横拉陰 } \\
\text { 部一ルぺ }\end{array}$ & $\begin{array}{c}(-) \\
0.5 \times 0.5\end{array}$ & $\frac{(-)}{0.5 \times 0.5}$ & $50.5 \times 0.5$ & $5(H)$ \\
\hline & & 0 & $\begin{array}{l}\text { 右側有痛 } \\
\text { 性横泫 }\end{array}$ & $\frac{(\mathrm{Ht})}{2.4 \times 3.0}$ & $\stackrel{(H)}{1.5 \times 1.8}$ & $8 \mid \begin{array}{c}(+) \\
1.3 \times 07\end{array}$ & $7(H)$ \\
\hline & & $\delta$ & 軟性下痜 & $\mid \begin{array}{c}\text { (H) } \\
2.5 \times 3.0\end{array}$ & $\begin{array}{c}(H) \\
1.5 \times 1.5\end{array}$ & $5 . \begin{array}{c}(-) \\
0.7 \times 0.7\end{array}$ & $7(-)$ \\
\hline & & $\delta$ & $\begin{array}{l}\text { 左側有痛 } \\
\text { 性横烧軟 } \\
\text { 性下痽 }\end{array}$ & $\begin{array}{c}(+) \\
1.0 \times 1.0\end{array}$ & $\mid \begin{array}{c}(+) \\
1.0 \times 1.0\end{array}$ & $\left(\begin{array}{c}(-) \\
0.7 \times 0.7\end{array}\right.$ & ( \\
\hline & & 3 & 痒 & $\begin{array}{c}(\mathrm{HW}) \\
4.0 \times 3.0\end{array}$ & $\begin{array}{c}(\mathrm{H}) \\
2.0 \times 1.5\end{array}$ & $5 . \begin{array}{c}(+t) \\
1.5 \times 1.5\end{array}$ & \\
\hline & & $\hat{\delta}$ & 軟性 & $\begin{array}{c}(+) \\
1.2 \times 1.2\end{array}$ & $\begin{array}{c}(+) \\
1.2 \times 1.2\end{array}$ & $2 \longdiv { 1 + 0 \times 1 . 0 }$ & $0(-)$ \\
\hline & & $\delta$ & 軟性下症 & f $\begin{array}{c}(+) \\
1.0 \times 1.0\end{array}$ & $\mid \begin{array}{c}(+) \\
1.0 \times 1.0\end{array}$ & $0 . \frac{(-)}{0.7 \times 0.7}$ & $7_{1}(-)$ \\
\hline & & $\hat{\delta}$ & 軟性ト痤 & $\mid \begin{array}{c}(+) \\
1.2 \times 1.2\end{array}$ & $\begin{array}{c}(+) \\
1.2 \times 1.2\end{array}$ & \begin{tabular}{l|l}
$\overline{(+)}$ \\
$1.4 \times 1.4$
\end{tabular} & \\
\hline & & $\hat{\delta}$ & $\begin{array}{l}\text { 左側有痛 } \\
\text { 性横聯 }\end{array}$ & - & $\begin{array}{c}(H) \\
2.0 \times 2.6\end{array}$ & $\left(\begin{array}{c}(-) \\
0.7 \times 0.7\end{array}\right.$ & $(\mathrm{HH})$ \\
\hline & & $\delta$ & $\begin{array}{l}\text { 右側化胀 } \\
\text { 性横炫 }\end{array}$ & (t) & $\begin{array}{l}(+) \\
1.0 \times 1.0\end{array}$ & $0 .(-)$ & \\
\hline & 30 & $\hat{\delta}$ & 觹頭㽷铜 & $(-)$ & $(-)$ & $(-)$ & $(-)$ \\
\hline & & $\hat{0}$ & $\begin{array}{l}\text { 左側化膿 } \\
\text { 性橫痃 }\end{array}$ & $\mid \begin{array}{c}(\mathrm{HA}) \\
2.0 \times 2.2\end{array}$ & $\begin{array}{c}(\mathrm{HI}) \\
2.0 \times 1.6\end{array}$ & $\begin{array}{c}(+) \\
61.2 \times 1.2\end{array}$ & $(H)$ \\
\hline & 24 & $\hat{\delta}$ & $\begin{array}{l}\text { 軟性下痻 } \\
\text { 左側有痛 } \\
\text { 性横烧 }\end{array}$ & $\begin{array}{c}(t+) \\
1.5 \times 1.2\end{array}$ & $\begin{array}{c}(t+) \\
1.5 \times 1.5\end{array}$ & $50.5 \times 0.5$ & $(-)$ \\
\hline & & $\hat{0}$ & $\begin{array}{l}\text { 侵刢性下 } \\
\text { 底 }\end{array}$ & $\begin{array}{c}(t+) \\
1.5 \times 15\end{array}$ & $=\begin{array}{c}(H) \\
1.5 \times 1.7\end{array}$ & $\begin{array}{c}(+) \\
1.0 \times 0.8\end{array}$ & $(-)$ \\
\hline & & $\hat{\beta}$ & 混合下疳 & $\begin{array}{c}(+) \\
1.0 \times 1.0\end{array}$ & $\begin{array}{c}(+) \\
1.0 \times 1.0\end{array}$ & $\begin{array}{c}(-) \\
0.5 \times 0.5\end{array}$ & (H) \\
\hline 18 & & s & 软的 & $\mid \begin{array}{c}(+) \\
0.8 \times 1 .\end{array}$ & $\begin{array}{c}(+) \\
1.0 \times 1 .\end{array}$ & $\begin{array}{c}(-) \\
0.5 \times 0.6\end{array}$ & $(-)$ \\
\hline
\end{tabular}

\section{總 括 及 ビ 考按}

診斷用トシテ北研製「シヤンケルワクチン」ヨ以テシタ余ノ經驗例八軟性下疳 27 例。軟性下疳

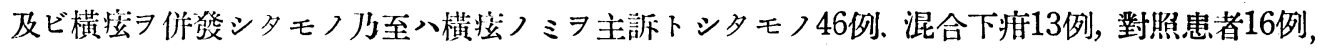
他ノ「シャンケルワクチン」トノ比校檢植例17例, 橫瘁治療=際シテ皮內反應习試ミタルモノ 11例，及ビ回顧現像卜見做スモノ1例合計131例デアル。

先ニ述ベタ如ク，0.1cc 7 皮內二注射シ24時間及48時間ノ二回二亘.ツテ局所ノ反應 $习$ 檢查シ 


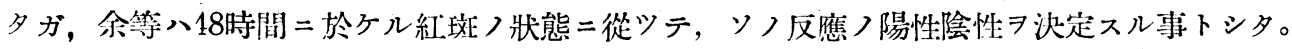
是八既= Reenstierna 氏尹始メ墸家ノ述ベテキル如ク，24時間後ノモノハソノ反應ガ時ニ非 特異性デアリ，48時間後ノモノガ伊東氏反應トシテ特異性デアルト思惟シタカラデアル。事實 余等モ24時間後二於テハ大ナル紅斑ヨ作ツタモノガ，48時間後二於テ全然消失シタ症例 キル。熊谷氏八傳研製「シャンケルワクチン」ヨ使州シテ伊東氏反應习試ミタ結果, 48時䦐後 ノ反應八， 21 時間後ノ反應ヨリモ幾分弱メラレテキル事习述ベテキル。余モ亦北研製「シャン ケルワワクチン」ヨ使用シテソノ感ガアルカニ思ヘル证例 7 觀察シタ。從ツテ余等八 48 時間後 二於テ直徑 1 粧以上ノ紅斑ヨ有スルモノヨ陽性トシタ。

份伊東氏反應八回顧現象 $\ni$ 特異的ニ示シ, Reenstierna 氏ノ追試モ本反應二力點 $\ni$ オテ キル。余ノ 1 例二於テモ此 7 認メル事ガ出來夕。只余ノ 1 例二於テハ殘念ナガラ約 1 ケ年間ノ 期間习經過シタ症例シカ經驗スル事ガ出狇ナカツタノデアルガ, Reenstierna 氏 $=$ 依レバ20年, 30年ノ永キ二亘ツテ本反應ノ陽性:ニ出ル事习述ベテキル。

余等ノ狂例二於テ反應ノ結果 出來夕。芸侙ミ症例ノ全部二於テ水疮乃至膿疮 自發痛ニ至ルマデノ種々ノ自覺症八程度ヨ異ニスルト八言へ各症例二於デ認メル事ガ出來夕。

余八全例二出來ル限り「フライ」氏反應习試ミント努メ夕。殊二第 2 裴ニ於テソウデアルガ, 余等八主トシテ伊東氏反應二重キフ置イタ篇「フライ」氏反應二依ツテ生ジタ紅斑ノ數字的ナ ルモノ八記載ヨ略シタ。而モ「フライ」氏反應ノ抗原ガ手部二少ナク,雼二各症例 $=$ 於テ試ミ ラレナカツタ事八殘念デアル。

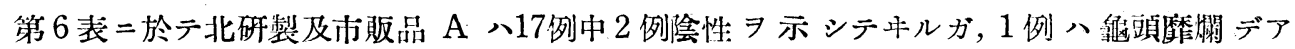
リ，1例八「ヘルペス」及横接ヨ筆ネタモノデアル，但シ後者八「ワ」氏反應(H)デアル故徽 毒性ノモノト思へル。市販品 $\mathrm{B}=$ 於テ, 僅カ = 6例二於テ陽性ヨ示シタ二過 ギヌ。他方伊柬 氏反應 7 試ミタ中直徑 1 糎以下>紅玟 $\ni$ 形成シタモ>八第 1 表=於テ 5 例, 第 2 表 = 於 テ 8 例, 第 3 表二於テ 2 例デ合計 15 例 7 算 スル。全症例 $=$ 就テ約 $10 \%$ ，㓌性率 見ル事卜 ナル。

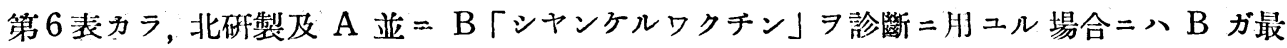
モ劣ツテ居ルニトハ一目瞭然デアルガ, 北研製卜 A トノ比較入甚ダ困難デアル。余ノ縃驗シ 夕症例二於テハ北研製ニテ陽性习示シタモノ八, A「ワクチン」 ア 以テシテモ陽性デアリ，北 研製ニテ陰性デアツタモノハ，A ヨ以テシテモ陰性デアツタ。唯異ル所八，北研製ニヨル反 應八 $\mathrm{A}=\Xi ル モ ノ=$ 比シテ幾分弱イモノガ多カツタト云フコトノミデアル。

之ヨ精細二觀察スルト，A「シャンケルワクチン」ニ於テ $(+)$ 或八 $(\mathrm{H})$ ノ場合八北㸴製モ

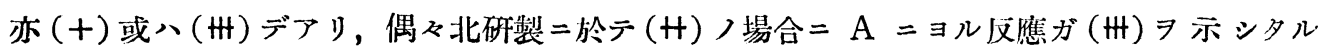


モノラ觀タルモノガア゙ツテ，兩者トモ充分診斷ノ目的二應朋シ得ルコトハ確言シ得ルガ，余ノ 僅カナル比較カラ兩者つ優劣习斷ズルコトハ出來ナイ。

\section{北硎製「シャンケルワクチン」二依ル獚痃治療}

橫瘁つ治療法トシテハ, 觀血的ニ腺摘出術ガ常テハ汎ク行ハレテ多。此ノ腺摘出ガ若シモ 不充分デアル時八，再ビ該所二腺腫脹ヨ認メル場合ガアル。又完全二腺摘出ヨナシ得夕場合下

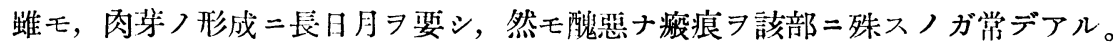

異種蛋白療法等ノ非觀血的療法モ亦行ハレテキタガ，總テ完全トハニカズ，ソノ治療成績 = 關シテ八諸萣ソノ報告ガ區々デアツタ。「ワクチン」製劑＝低ル非觀血的療法ガ以後二於テ試ミ ラレ，1930年廣瀨氏ニ依リ「ブボークリンヒツト」ガ侴製セラレタ。之二就テ八龜田，岩崎， 皆見, 木田，藤田，橋本，木下氏等ノ報告ガアツテ何レモソノ腣果习認メテキル。

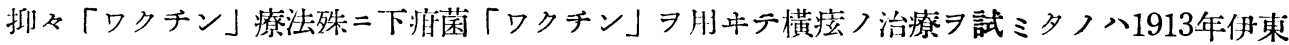
氏ヨ以テ最初ノ人トスル。ソノ後栗朋，久保山氏等ノ追㑝ガアツタガ「シヤンケルワクチン」フ 靜脈內二使打シタノハNicolle- Durando 氏デ, 1924年始メテコレヨ實施シタノデアル。1934年

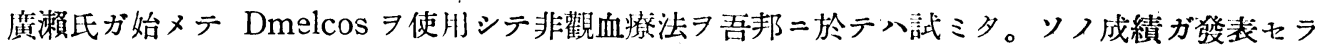
レルヤ, 何人モソノ偉效 7 容認スルニ至リ, 更二淺見, 遠山、术川氏等ノ追試二依ツテDmelcos八

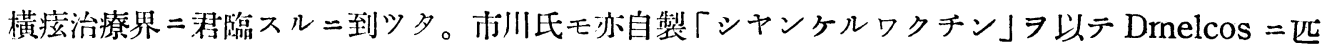

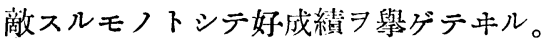

而シテ文献习徵スルニ, 現在迄施行セラレテキル「ワクチン」静脈內乃至八等筋內注射 $=ョ$ ル横瘁非觀血的燎法八，ソノ「ワクチン」使用量及方法ヨ諸家ニ依ツテ，伊東氏反應二於ケルト 同樣區々ニシテキル。

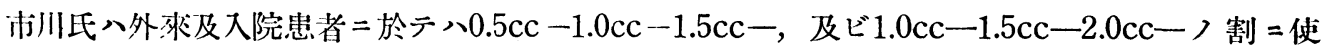

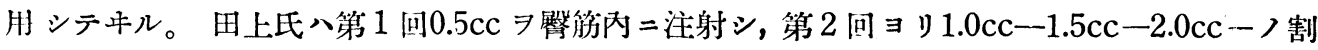
二使用 シテキル。淺見氏 八田上氏ノ方法卜同樣ナ方法习採リ，石津氏八第 1 回0.4cc 第 2 回 $0.8 \mathrm{cc}$ 万至八 $1.0 \mathrm{cc}$ ，第 3 回八 $1.0 \mathrm{cc}$ 乃至 $1.5 \mathrm{cc}$ フ割二靜脈注射

翻ツテ余等ノ探レル方法ハ北研製「シャンルワクチン」ヨ第 1 回量 $0.1 \mathrm{cc}$, 以後大體=於テ $0.1 \mathrm{cc}$ 宛增量乃至八第 1 回量ノ等差級數的增量 ガ 1 日平熱狀態デアル事ヨ以テシタ。郎大體二於テ隔日又八 2 日每=注射シタノデアルガ，顯 著ナル副作朋习認メタモノハナイ。只 2 例二於テ食欲不振及不眠ヨ訴ヘタ二過ギナイ。

以下ソノ經過ヨ表記スレバ次ノ如クデアル。 
第 7 表

\begin{tabular}{|c|c|c|c|c|c|c|c|c|c|}
\hline 番患年| & $\begin{array}{l}\text { 在 } \\
\text { 院 } \\
\text { 日基 } \\
\end{array}$ & \begin{tabular}{l|l} 
回 & 最 \\
數 & $\mathrm{ccm}$ \\
\end{tabular} & 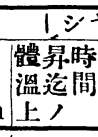 & $\begin{array}{l}\text { ヤンケル } \\
\text { 最高體溫 }\end{array}$ & $\begin{array}{l}\text { ワクチン 靜脈注射 } \\
\text { 盟| 熱 }\end{array}$ & \begin{tabular}{|l} 
持間 \\
縕 \\
時
\end{tabular} & 横 㾦 所 見 & \begin{tabular}{|c|} 
治 \\
潦 \\
他 \\
\end{tabular} & 備 \\
\hline $1 \mid ⿰ \mathrm{st}-40$ & 1 & & & & & & $8.0 \mathrm{~cm} \times 5.5 \mathrm{~cm}$ & & 軟性下疷アリ \\
\hline & 2 & $1 \cdot 0.1$ & $4.0 \mathrm{St}$ & $40.4^{\circ} \mathrm{C}$ & 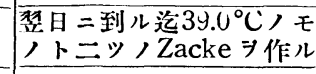 & $6 \mathrm{St}$ & 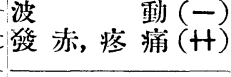 & & $\begin{array}{l}\text { 桝東氏反應(+) } \\
\text { フライ氏反鷹 }\end{array}$ \\
\hline & 3 & & & & & & $7.7 \times 5.5$ & & $(-)$ \\
\hline & 4 & 20.2 & $2.5 \mathrm{St}$ & $40.3^{\circ} \mathrm{C}$ & $\begin{array}{l}40 .{ }^{\circ} \mathrm{C} \text { ノモノトニッ/Za } \\
\text { cke ヨ作ル }\end{array}$ & $16 \mathrm{St}$ & $6.5 \times 5.3$ & & ワ氏反應（一） \\
\hline & 5 & & & & & & $6.0 \times 4.5$ & & 副 作 用 (一) \\
\hline & 6 & 3.0 .3 & $1.5 \mathrm{St}$ & $40.3^{\circ} \mathrm{C}$ & 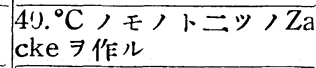 & $12 \mathrm{St}$ & $4.5 \times 4.5$ & & \\
\hline & 7 & & & & & & $4.0 \times 3.7$ & & \\
\hline & 8 & 40.4 & $1.5 \mathrm{St}$ & $40.3^{\circ} \mathrm{C}$ & $\begin{array}{l}\text { 同漛 ナル Doppeltzacke } \\
\exists \text { 作ル }\end{array}$ & $5 \mathrm{St}$ & $3.7 \times 3.3$ & & \\
\hline & 9 & & & & & & 小指 頭 大 & & 退院。 \\
\hline 2 中 $31^{\prime} \delta$ & 1 & & & & & & $6.0 \times 9.0$ & & 伊東氏反隼(一) \\
\hline 村 & 21 & $\mid 0.1$ & $0.5 \mathrm{St}$ & $40.2^{\circ} \mathrm{C}$ & 禁日迄 $400^{\circ} \mathrm{C}$ ᄏ超ユル & $24 \mathrm{St}$ & 潑赤(tt) 療着( & & 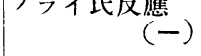 \\
\hline & 3 & 筑熱 & 獎態 = & $=ア リ$ & モノ1ッアリ & & 動 $(H)$ & & \\
\hline & 4 & & & & & & $4.8 \times 6.5$ & 小 & \\
\hline & 5 & & & & & & 波 動 著 明 & 贸 & \\
\hline & 6 & 20.1 & $0.5 \mathrm{St}$ & $40.6^{\circ} \mathrm{C}$ & $\begin{array}{l}40^{\circ} \mathrm{C} \text { 以上ノ Zacke } 2 \zeta \\
\text { 生 }\end{array}$ & $17 \mathrm{St}$ & $3.5 \times 3.0$ & & \\
\hline & 7 & & & & & & 唡 指 頭 大 & & 退院。 \\
\hline 3渡 21 . & 1 & 10.1 & $1.5 \mathrm{St}$ & $39.4^{\circ} \mathrm{C}$ & $\begin{array}{l}39^{\circ} \mathrm{C} \text { 以上ノ Zacke } 2 \text { ケ } \\
\text { 生ズ }\end{array}$ & $14 \mathrm{St}$ & $4.0 \times 5.0$ & & 東伊氏反雔(+) \\
\hline 硰 & 2 & & & & & & 痖青 & & フフイ氏反睢 \\
\hline & 3 & 20.15 & $1 \mathrm{St}$ & $40.3^{\circ} \mathrm{C}$ & 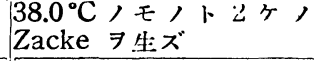 & $13 \mathrm{St}$ & $3.0 \times 4.5$ & & 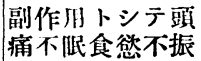 \\
\hline & 4 & 1 & & & & & & & F訴 \\
\hline & $5:$ & 30.25 & 1St & $39.4^{\circ} \mathrm{C}$ & $\begin{array}{l}39^{\circ} \mathrm{C} \text { 前後 } \\
\text { 生ズ Zacke } 3 \text { r }\end{array}$ & $10 \mathrm{St}$ & $2.0 \times 2.0$ & & \\
\hline & 6 & & & & & & 小指 頭 大 & & \\
\hline $4 \mid$ 传 31 余 & 1 & 10.1 & $0.5 \mathrm{St}$ & $40.3^{\circ} \mathrm{C}$ & $\begin{array}{l}\text { 漸次下降シ著明ナル } \\
\text { Zacke ナシ }\end{array}$ & $34 \mathrm{St}$ & $5.0 \times 5.0$ & & 仹東氏反睢(H） \\
\hline 藤 & 2 & & & & & & 谈赤 $(+)$ & & 下疷アリ \\
\hline & 3 & 20.15 & $1 \mathrm{St}$ & $39.9^{\circ} \mathrm{C}$ & $\begin{array}{l}39^{\circ} \mathrm{C} \text { 嫋 Z Zacke 卜共 = } \\
2 \text { 3生ズ }\end{array}$ & $20 \mathrm{St}$ & $3.3 \times 3.3$ & & 食笖不振 \\
\hline & 4 & & & & & & & & 不＼cjkstart腿 \\
\hline & $5:$ & $\begin{array}{lll}3 & 0 & 25\end{array}$ & $05 \mathrm{St}$ & $40.2^{\circ} \mathrm{C}$ & Zacke ナシ & $15 \mathrm{St}$ & $3.0 \times 2.7$ & & \\
\hline & 6 & & & & & & & & \\
\hline
\end{tabular}




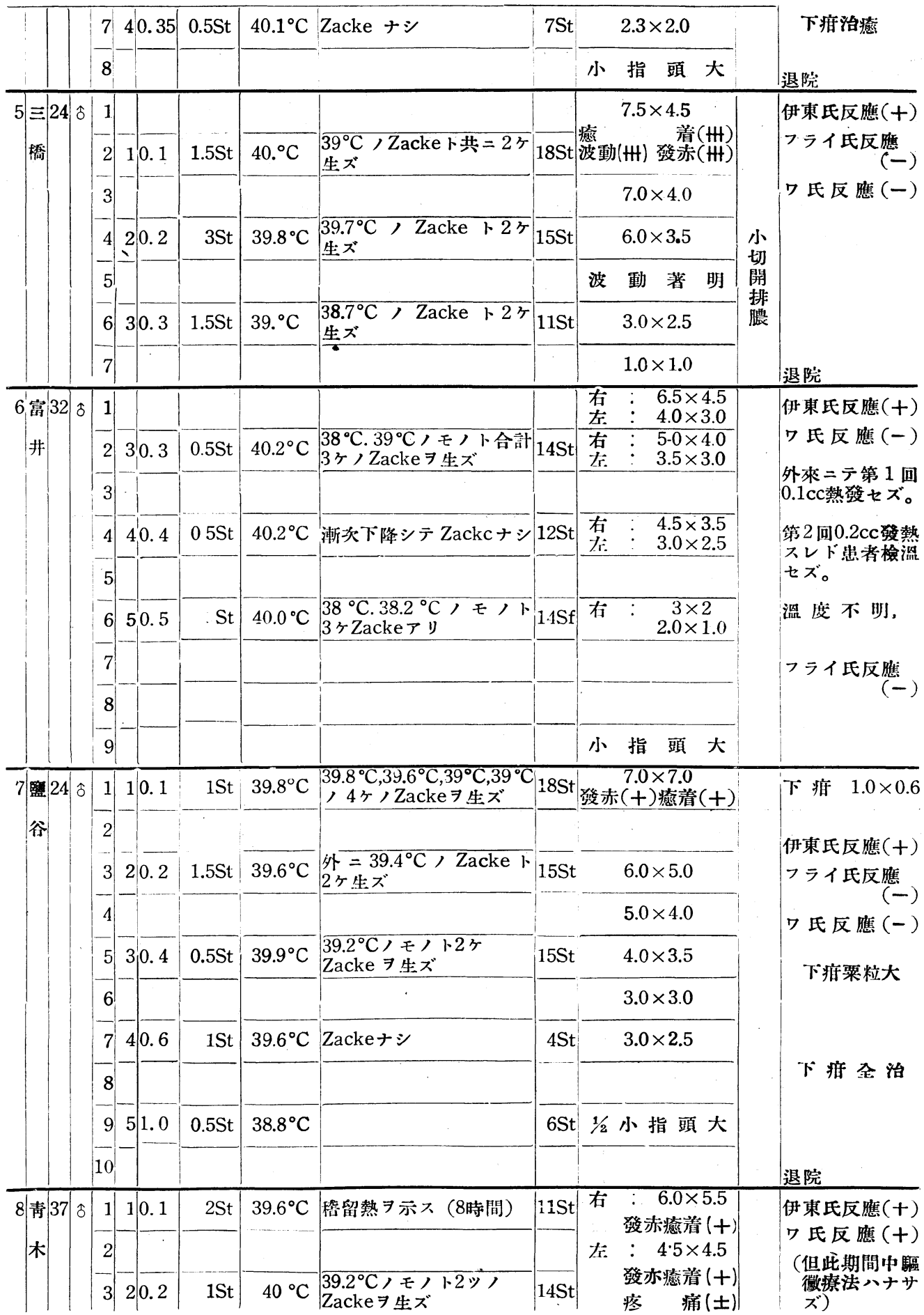




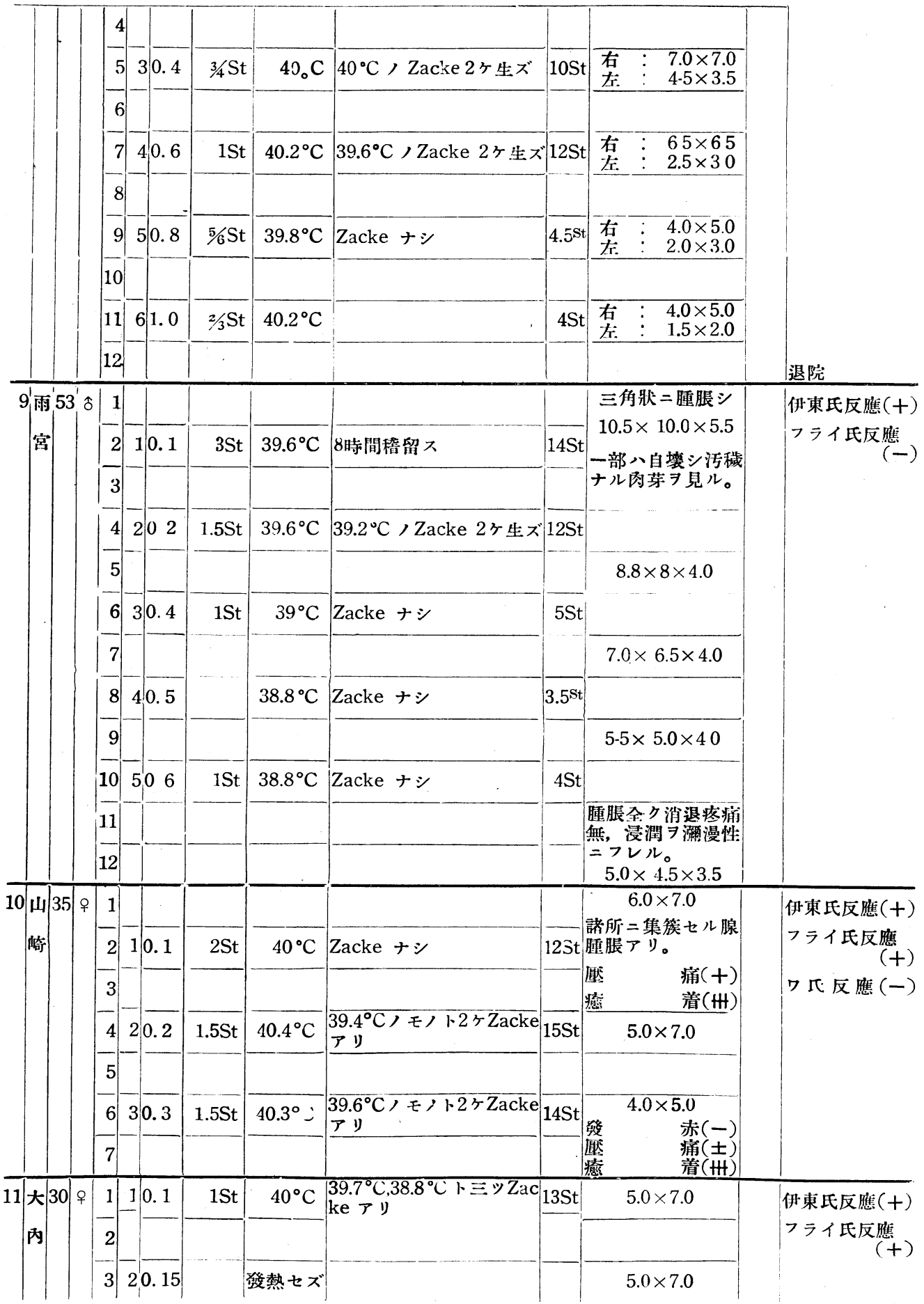




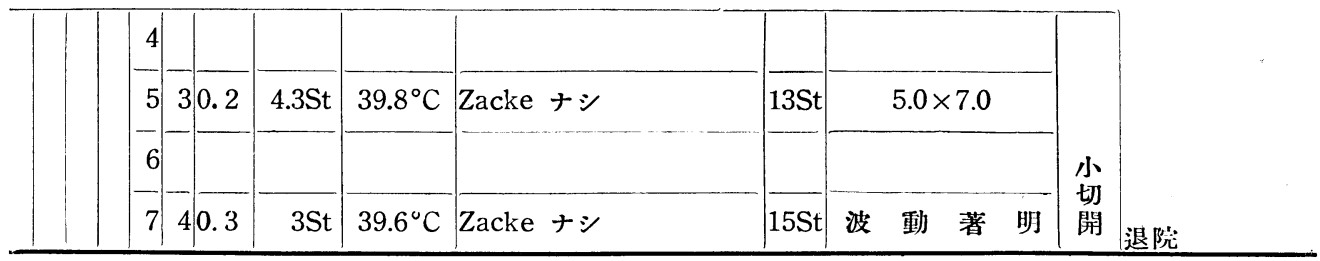

按

北研製「シャンケルワクチン」二依ル橫瘁非觀血療法习施シタ 11 例习記載シタ。佾此ノ外二 外來二於テ靜脈內注射 7 施行シタモノモアルガ，此處ニ八熱型ノ詳細ナルモノラ必要トシタ篇 ニ入院セシメタモノノミヨ採ツタ。11例二就テ觀察スルト6例=於テハ完全二奏効シ，3例二於

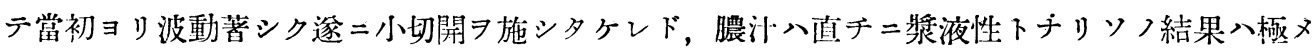
テ良好デアツタ。即波動ノ著明ナルモノハ之ヨ完全二吸收セシメル事八不可能デアツタ。他ノ 2 例表中 10.11 例八同時ニ「フライ」氏反應陽性ナルモノデアツタガ或程度以上二八腫張ハ減退七 シメル事ハ出來ナカソタ。郎第 4 性病ノ混在セルモノニアツテハ本「ワクチン」ヨ朋年テノ發熱

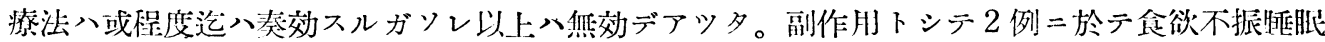
障碍, 䫓痛等: 認メ夕。

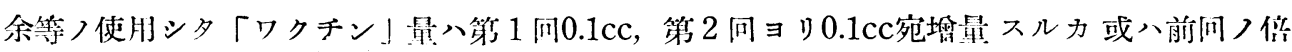
量习使肞シタ。使胿全量八最低 $0.3 \mathrm{cc}$ 最高 $3.1 \mathrm{cc}$ 斗均 $1.2 \mathrm{cc}$ 弱デアル。之ヨ諸家ノ使用量二比校ス

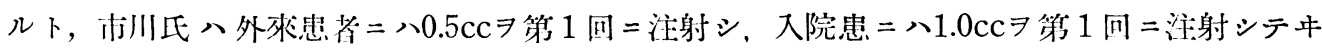
ル。ヌソノ他多クノ報告ハ大體ニ於テ第 1 回量 $70.5 \mathrm{cc}$ 冈外トシテ问ヨ重ネル等=0.Ecc宛 量シ 全问數4-5-6-7回＝及ンデキル。遠山，市川氏等八第 1 同ノ注射量ハ50「ミリオン」以 .上，總最500 600「ミリオン」ニテ充分ナル場合ガ多ク，標準量デハ「ワクチン」浪䩀つ感ナキ シシモアラズト述ベテキル事八，余等ノ「ワクチン.|使䭪ヨリ考へテ味フベキモノガアルト 思フ。

注射问數八最低 2 回, 枝高 6 回, 本均 4 回デアッタ。體溫上昇迄二要 スル 時間八, 最モ早

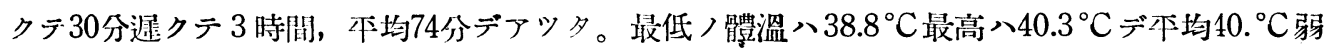
デアル。余等ノ註:例二於テ興味アル事ハ，殆ンドノ熱型=於テ Doppeltzacke ヨ認メテキル 事デアル。コレハStümpke 氏モ既二記載シテキル事デアルガ，一般=發熱療法ヨ行ツタモノ つ熱型二就テ觀ルト急激二没熱シ最高熱二達スルト漸次激散狀態 菌「ワクチン」二低ル谁熱療法つ際二坟モョク見ラレルモノデアル。

余ノ試ミタ北研製「シヤンケルワクチン」ニ依ル發熱療法ノ經過中二於ケル熱型ヨ見ルニ，

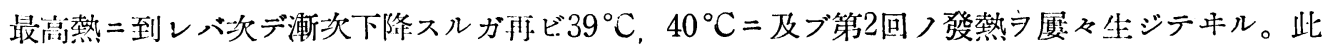
フ際ニ於ヶル第2 Z Zacke 八第1 Zacke ヨリハ低イノガ常デアル，如何ナル機轉 =テ此 
Doppeltzacke ヨ生ズルカ不明デアル。或モノハ注射量ノ多イ事カ原因ノーツデアルト言ツテ

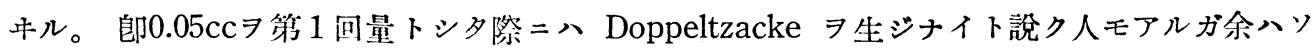
レヨ賽施シテキナイノデソノ當否入說明出來ナイ。佾比ノDoppeltzacke ガ橫痃治療上二如 何ナル影響フ及ボスカ不明デアル。カクシテ $38^{\circ} \mathrm{C}$ 以上つ發熱狀態ニアル期間入最長 34 時間，最

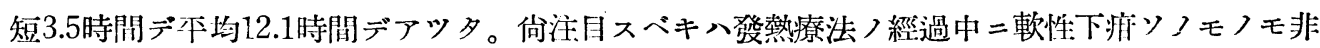
常二良好ナ經過ヨトルトイフ事デアル。

\section{結論}

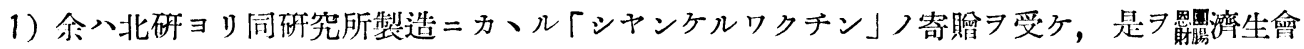
芝病院皮膚科泌尿器科外來及入院患者二就テ，伊東氏反應及ビ「シヤンケルワクチン、静脈 內注射 $=ヨ ル$ 橫瘁ノ非觀血的療法二試ミタ。

2) 實驗例 總數131例デアツテ, 軟性下将27例, 軟性下底=横瘁 ノョ訴ヘテキタモノ49例，混合下疳13例，回顧現象トナスベキモノ1例, 對照例16例，北研 製「シャンケルワクチン」ト比較シタルi販「シヤンケルワクチン」(假リ＝A及Bトス)使 的例17例，及橫痹治療患者11例デアル。

3）仾東氏反應決定八，抗原皮內注射後 48 時間二於テ局所ノ紅斑习檢シ，直徑1.0栕以上ノモノ

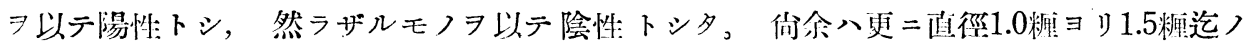
$\Rightarrow(+), 1.5$ 糎ヨリ2.0湹迄ノモノ

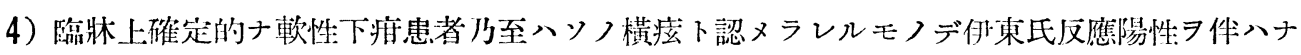
カツタモノ八，第 1 表二於テ 5 例郎 $18 \%$ ，第 2 表二於テ 8 例剆 $17 \%$ ，第3表=於テ 2 例郎 $15 \%$ 第6表二於テ1例 $6 \%$ 。横㾦治療患者二於ケル例東氏反應二於テハ100\%ノ陽性デアツタ。之 フ總數つ百分率カラミレバ約 $90 \%$ ノ陽性率トナル。

5) 北研製「シヤンケルワクチン」ト比較使用シタ市販「シャンケルワクチン」ノ成績八第 6 泰 二表示シタ如ク $\mathrm{B}$ 最モ劣リ，北研製ト $\mathrm{A}$ トノ比較八困難デアル。

6）橫瘖治療患者11例ノ冈6例八全治シ，3例八當初ョリ波動著明ニシテ中途デ小切開 ヨ加へタ ガ膿汁八百チニ漿液性トナリソノ經過入極メテ良好デアッタ。2例＝於デ或程度以上横 瘁ハ縮小シナカツタ。コノ2例ニハ「フライ」氏反應ノ陽性:出ティタモノデアル。使用量入 平均 $1.2 \mathrm{cc}$ 弱デ箔家ノソレニ比シテ甚ダシク僅少デ敢へテ大量使䏳スル必姴ハナイト思フ。

7) 余ノ試ミタ發熱療法ノ熱型中デ興味アル事ハDoppeltzacke ヨ生ジタ事デアル。Doppeltzacke つ第 2 Zacke 八第 1 Zacke $ョ$ リ低イ。此ノDoppeltzacke ノ成因及意義八不明 デアル。 


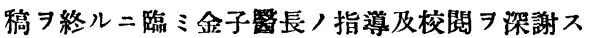

\section{主 要 文 献}

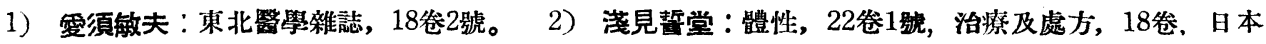
醫事涸報, 2003號。 3 ） 石津 俊, 信岡 澄: 皮尿誌, 41號, 2號。 4）市川篤二, 使田倫三 體性，22卷12號，23卷 3 號，4號，24卷 4號。5）橋本 雷：皮尿誌，28卷 9號。6）熊谷 晃 皮卜泌，6兊 3 號。 7） 木元興之, 北 斐夫, 內村民雄：皮尿誌，37怣 5 號。 8） 本幡正交, 木元興之, 北 韭夫：皮尿誌, 37焱 3 號。 9）田口艮雄：皮尿誌, 38卷 1號。 10）逨山郁三, 市川篤二, 葆田倫三：皮尿誌，38卷 1號。 11）田上初雄：皮尿誌, 42卷 3號。 12）木田：

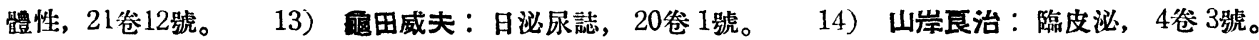
15）渡䢜繁彌：細菌學雜誌，510號。 